\title{
Theology, the Fairy Queen
}

\author{
Tomoko Masuzawa*
}

Department of History and Department of Comparative Literature, University of Michigan

${ }^{*}$ Corresponding author. E-mail: masuzawa@umich.edu

Scholars of religion today understand that the scientific basis of religious studies lies in the fact that religion is a multifarious historical phenomenon accessible through empirical research, and that this study therefore differs fundamentally from theology premised on the acceptance of supernaturally revealed truths and faith traditions. Meanwhile, it has been broadly believed that theology once occupied the preeminent position in the medieval university, as expressed by the well-known sobriquet "queen of the sciences." By surveying the early history of the university, this article shows that most medieval universities did not have a theology faculty until the fourteenth century. With the notable exception of Paris and its immediate offspring (Oxford and Cambridge), the relation between theology and the university was far more tangential and temporizing than is generally assumed-a point worth bearing in mind as we consider the question of the secularization of learning, which is said to have taken place since the early modern period.

\section{History's religion: a modern anxiety}

Owing to certain contingencies not easily described in brief, "history of religion"or, alternatively, "history of religions"-has become one of the standard American appellations for the study of religion conducted in the universities. Although it is now more common to designate the whole enterprise inclusively and rather vaguely as "religious studies," before this terminological settlement there had been several loose synonyms naming more or less the same thing, or similar enough things, all dating back to the nineteenth century. Among them were "comparative religion," "comparative history of religion" (Vergleichende Religionsgeschichte), and "science of religion" (Religionswissenschaft; science des religions). Though thus varied, this cluster of nomenclature collectively signals some self-defining characteristics of a distinctly modern kind of scholarly endeavor; that is, distinct and different from another kind, of much longer standing. This other, older sort of "religious studies," as practitioners of the newer science are wont to aver, was predicated on altogether different principles and premises, and it flourished not in the university but rather in ecclesiastical and monastic institutions. It is pointedly asserted, moreover, that, in contrast to this fideistic scholarly exercise, the properly academic study of religion is predicated not on any creedal tenets or scriptural traditions but solely on documentary, ethnographic, archaeological, and other kinds of empirical evidence, as well as on sound reasoning and research methods commensurate with all other sciences. In effect, the aforesaid cluster of nomenclature concertedly 
implies that, by virtue of being rendered an object of historiographic description and documentation, religion has become for the first time an eminently suitable subject to be studied publicly by anyone; as such, this scholarship is fit for integration into a system of public education, especially at the university level, even under a stringent regime of church and state separation.

It may be thought curious that today's practitioners of the academic study of religion are not particularly keen to call this scholarship secular, except in certain specific contexts, mostly having to do with litigation or legislation. ${ }^{1}$ This is not the place to speculate on the full gamut of reasons that might account for anyone's reticence to ascribe outright secularity to the academic study of religion. ${ }^{2}$ That said, there is room enough to wonder just what unwelcome complications could ensue if one were to call it secular and to cite that fact as grounds for its legitimacy within the (presumably secular) academy. ${ }^{3}$ One of the complicating factors could be the enduring presence of theology in many prominent institutions of higher learning today, often as a subfield or a subspecialty within the domain of religious studies.

But what is theology? While the appellation "religious studies" has been more or less stabilized in recent decades owing to its regular presence in the university curriculum, the term "theology" appears to be volatile, its definition up for grabs. The term is liable to turn up as a stock fighting word among religion scholars, enlisted by anyone who aims to stake out a position, pick a fight, or settle scores by weaponizing the term, pro or con, to suit whatever purpose at hand. In short, today's learned profession seems confused, at times wildly equivocal, about what theology is, or what it is supposed to have been in the past. This state of affairs is markedly dissonant with a well-known fact that an organ called "the faculty of theology" or "divinity" has been part of the university since the Middle Ages. Most commonplace accounts of the history of the university would rehearse that theology, alongside law and medicine, was one of the three "higher faculties" of the medieval university. ${ }^{4}$ Theology was often called the first faculty, we are told, in due reverence, presumably, to its subject matter. How, then, did theology become so alienated from the very institution in which, as it is often alleged, it once reigned as queen?

\footnotetext{
${ }^{1}$ An oft-cited example is the landmark US Supreme Court case Abington Township v. Schempp (1963), wherein the daily exercise of reciting a passage from the Bible in public schools was found unconstitutional. The court opinion famously added a qualifying statement: "it might be said that one's education is not complete without a study of comparative religion or the history of religion and its relationship to the advancement of civilization. It certainly may be said that the Bible is worthy of study for its literary and historic qualities. Nothing we have said here indicates that such study of the Bible or of religion, when presented objectively as part of a secular program of education, may not be effected consistently with the First Amendment." 374 U.S. [1963] at 225, emphases added. Although the case did not pertain to curricula in higher education, some American scholars of religion consider this decision an important legal justification for instituting a program of religious studies in public universities. For a critical assessment of this claim see Sarah Imhoff, "The Creation Story, or How We Learned to Stop Worrying and Love Schempp," Journal of the American Academy of Religion 84/2 (2016), 466-97.

${ }^{2} \mathrm{~A}$ significant minority of religion scholars identify their work as secular, many of whom are strongly represented in the International Association for History of Religions (IAHR) and the North American Association for the Study of Religion (NAASR).

${ }^{3}$ This may be in part due to the opinion that a "secular study of religion" would amount to an antireligious study of religion, which opinion, however, most religion scholars would dismiss as patently misguided.

${ }^{4}$ This was true in some, but not all, of the medieval universities, as we shall see presently.
} 
Today, most denizens of the university appear to take little cognizance of theology where it is still extant; their sentiments often range from low-grade reproof to condescension, if not plain indifference. The venerable science with God as its grounding concept may be thus ignored or considered a fossil, perhaps something to do with the institution's past denominational legacy. This no doubt is one of the reasons why the self-styled modern scholar-scientists of religion are eager to differentiate their enterprise from theology as thus perceived. These scholars make a point of insisting that religion can be objectified and historicized; that is, recognized as an object defined by empirical evidence, and not as a premise or a precondition of some special kind of knowledge. But if this should be the difference between the old and the new sorts of "religious studies," then how did the transformation from theology to science of religion, or this displacement of the fideistic study of God's revelation by the scientific "history of religion(s)," come about? Some kind of explanation is called for, and that explanation itself must be historical.

Of course, such explanatory narratives abound, and for the most part they follow a familiar plotline that can be called the standard secularization narrative. Whatever the variation, this narrative assumes that people in premodern times were far more religious in their outlook than we are today, and accordingly ecclesiastical authorities exercised far greater control over the society, and that temporal rulers and civil authorities were far more likely to be in alliance, be it agonistic or conniving, with religious institutions and their personnel. Hence, this narrative implies, theology qua "science of God" was an overweening presence in the medieval university, and through the offices of this preeminent faculty, the university served the needs and interests of church and state in the course of fulfilling its own intrinsic purpose. This condition began to change in the West, so the story goes, in the early modern period, when the hegemonic reign of the Roman Church was permanently lost; the ecclesiastical and political breakup of Latin Christendom, combined with the new discovery of hitherto unknown worlds and re-cognition of non-Christian traditions as other religions, ushered in a new era, in which the new science of religion was but one eventual outcome. ${ }^{5}$

This narrative is thus both tragi-heroic and triumphal at the same time; it is about a loss and about an overcoming of what once had been. Observed on either side of the sentiment, it is a story of an irreversible break with the past. Perhaps because of the very structure of the narrative, however, there lingers a doubt, and also an anxiety. Was the break clean? Did the centuries-long process of secularization really allow academic disciplines (study of religion included) to come into their own, outgrowing servile submission to the tutelage of ecclesiastical authorities, liberating themselves from the fetters of providential teleology, and finally learning to "speak for themselves," as it were, thus achieving their Mündigkeit? If this is the basic plot of scientific maturation, it seems inexorable that the transition from

\footnotetext{
${ }^{5}$ This scenario has long been an undercurrent of how the disciplinary history of the study of religion has been told, though the theme of secularization tends to be more nuanced and less linear. See, for example, Jan de Vries, The Study of Religion: A Historical Approach, trans. Kees W. Bolle (New York, 1967); Eric J. Sharpe, Comparative Religion: A History (La Salle, 1975). For a more recent account that stresses the significance of the early modern period, see Guy G. Stroumsa, A New Science: The Discovery of Religion in the Age of Reason (Cambridge, 2010). Cf. also Yosef H. Yerushalmi, Zakhor: Jewish History and Jewish Memory (Seattle, 1982).
} 
"theology" to "religious studies" was effected by the thorough historicization of its central object-that is to say, by the transformation of "religion" as an object of attention from the content of revelation to the data of history. But if so, it seems natural, and therefore easy to understand, that there should be persistent worries about the completeness of this transformation, about the possible furtive remainder: history's religion. What if some residual theology lurks in the penumbra of modern scientific historiography, if not in its very heart?

But this question already presumes too much. To examine "history's religion" critically, and to diagnose correctly the anxiety disorder associated with it, must mean more than arguing about the moment of the alleged break, its nature, its extent, or its possible illusoriness. Rather, it is the construction of a particular image of the past-a picture of "before"-that should first come under scrutiny. Here, it is not my intention to challenge the secularization narrative tout court, or any particular version thereof. The aim of this article is limited to casting a cursory glance at the medieval university and the position of theology in relation to it, in the hopes of arriving at a preliminary assessment of one of the key premises of this desolation-liberation narrative.

How wrapped up in religion were the Middle Ages? How domineering a presence was theology in the medieval university? The first question may be too nebulous; but regarding the second, some empirical bases for answering it begin to suggest themselves.

Activities that we today would call theological obviously have been going on for a long time. In the context of the western hemisphere and of Christianity in particular, we might say that these activities go back to the days of Church Fathers, when certain prominent proponents of various Jesus movements populating the Mediterranean world in the early Christian centuries were deliberating, proclaiming, and disputing among themselves. As of the fourth century, moreover, the stakes at these contestations were elevated significantly under imperial patronage, for with this privilege came added pressure, in the form of ecumenical councils and recurrent imperial mandates, to come to some kind of agreement, in the interest of arriving at a singular creed of universal orthodoxy befitting the universal empire-the goal, however, that was never to be achieved. Christian apologies and creedal justifications in the face of unbelieving opponents, and then ever more exacting articulations and specifications of what is right to believe and to profess-these discursive activities we may reasonably call theology, even if the protagonists themselves did not at the time. ${ }^{6}$ Meanwhile, theology as an academic discipline and as a curricular component within the university-an institution new to the West beginning in the twelfth century-this is an altogether different matter. ${ }^{7}$

\footnotetext{
${ }^{6}$ Pelikan reports-here quoting Marie-Dominique Chenu, La théologie au douzieme siècle (Paris, 1966) -that the notion of theology as "an organized and learned understanding of the data of revelation" developed only gradually and had not yet been established in the Middle Ages. Jaroslav Pelikan, The Christian Tradition, vol. 3, The Growth of Medieval Theology (Chicago, 1978), 5.

${ }^{7}$ On this general subject see G. R. Evans, Old Arts and New Theology: The Beginnings of Theology as an Academic Discipline (Oxford, 1980); Ulrich Köpf, Die Anfänge der theologischen Wissenschaftstheorie im 13. Jahrhundert (Tübingen, 1974); Wolfhart Pannenberg, Theology and the Philosophy of Science, trans. Francis
} 
The idea that academic theology evolved from those ancient discursivities naturally, organically, and intrinsically, or that theology found its preeminent position within the university curriculum from the beginning, however familiar such a storyline, is not supported by historical evidence. By the same token, the presumption that the university emerged as an institution saturated with theological interests, or that the university was founded under the sway of ecclesiastical authorities intent on doctrinal correctness, all that is demonstrably false. In fact, as we shall see in the following pages, with notable exceptions of Paris, Oxford, and Cambridge, theology did not constitute a regular faculty in any of the universities of medieval origin; that is, not until the late fourteenth century.

Accordingly, the strategy employed in what is to follow is, first, to sideline these commonly assumed notions about the medieval university, and, along the way, to begin to speculate why the facts to the contrary are not better known among us today. More specifically, this means recalibrating our perspective on the medieval universities, which has hitherto been focused disproportionately on the examples of Paris and its offspring, all of which were in the north, and to recognize instead Paris as an exception rather than the prototype. At the same time, we will also note that, exceptional though they were, the original trio of theology-equipped universities also exhibited some of the same tendencies observed in the more typical specimens of the medieval institution. The profiles of those other, indeed more typical, universities in the south attest that the fields of knowledge that defined the university education in those early centuries were the new sciences, philosophies, and medicine lately imported from the Greco-Arabic worlds, as well as-and arguably most importantly-law. In any case, it was not theology. And this should surprise no one if we keep in mind that the instigating factors that brought the university into existence in the first place were literally foreign to Latin Christendom; as such, the wealth of new knowledge dispensed at the university was initially dissonant with the native creedal traditions of the Western Church.

In order to reset our perspective, then, we shall begin by rehearsing the early history of the medieval universities with due attention to the overall circumstances of their arising in the twelfth century. Facts pertaining to this history are well known to many medievalists, though their individual accounts tend to be rather particularly focused in accordance with their respective specialties, and, on the whole, heavily weighted toward the northern institutions modeled after Paris. ${ }^{8}$ We in turn aim to bring into view a rough sketch of the whole, by sampling from this sprawling and disjointed collection of the regionally delimited, often institution-specific, and at times somewhat solipsistic accounts. It will be noted that there was a great deal of divergence between the Paris-centered north and the Italianate south, ${ }^{9}$ especially with regard to the university's internal organization, as well as its relation to external authorities, be they municipal, royal, imperial, or ecclesiastical.

McDonagh (London, 1976); Étienne Gilson, History of Christian Philosophy in the Middle Ages (New York, 1955).

${ }^{8}$ Cf. Paul Oskar Kristeller, "The Curriculum of the Italian Universities from the Middle Ages to the Renaissance," in Kristeller, Studies in Renaissance Thought and Letters, vol. 4 (Rome, 1996), 75-96; and Paul F. Grendler, The Universities of the Italian Renaissance (Baltimore, 2002).

${ }^{9}$ The South here would also encompass the so-called Midi, the southern part of France today, but not part of the kingdom of France during the Middle Ages. 


\section{Origin of the university}

As pioneering American medievalist Charles Homer Haskins famously put it, universities were among those medieval things that "had no founder or fixed date of beginning but instead 'just grew,' arising slowly and silently without definite record." ${ }^{\text {To }}$ The university at first was but a spontaneous "swarming" of people: on the one hand, those desiring to acquire some new knowledge that was not locally available (students, or "scholars" in the earlier terminology), and on the other, those who already possessed something of that knowledge and were willing to impart it to others (professors, or "masters"). In effect, what constituted the medieval university-or studium generale, as it was more commonly called at the beginning-was the self-formation of a guild. Despite the significance attributed to various sanctions that came in the form of papal bulls and royal or imperial charters, what defined the character of the medieval university was not those official permissions and benedictions but something that took place before them. ${ }^{11}$ Elaborating further, Haskins explains that the word "university" meant "a group or corporation in general, and only in time did it come to be limited to guilds of masters and students, universitas societas magistrorum discipulorumque." "Historically," he asseverates, dispelling a common misconception, "the word university has no connection with the universe or the universality of learning; it denotes only the totality of a group, whether of barbers, carpenters, or students did not matter." 13

As with all trade-specific unions, the university first came to organize itself in order to protect the interests of those who thus gathered from afar for shared purposes. Broadly speaking, there were two types of guild: one epitomized by the University of Bologna and other southern universities, where the guild of scholars was primary, and the other type exemplified by the University of Paris and its northern progeny, where the guild of masters was predominant. Either way, the guild aimed to curb undue interference into university affairs by the local authorities, be they magistrates or bishops. And it was to these purposes of collective defense and protection that the charters issued by a loftier authority were especially meaningful. In sum, as James Brundage more recently put it, "All universities relied on recognition by outside authorities, such as kings, popes, and municipal governments, to legitimize and protect the rights and privileges that their members coveted, but the earliest universities emerged in consequence of spontaneous actions by students (as at Bologna) or masters (as at Paris and Oxford), without the intervention of any

\footnotetext{
${ }^{10}$ Charles Homer Haskins, The Rise of Universities (Ithaca, 1957; first published 1923), 4.

${ }^{11}$ Haskins's thesis here is to be distinguished from the idea-represented for example by Herbert Grundmann in his Vom Ursprung der Universität im Mittelalter (Darmstadt, 1957), according to Brundage - that the universities emerged out of "love of knowledge" independent of political, ecclesiastical, or socioeconomic interests. James A. Brundage, "The Medieval Battle of the Faculties: Theologians v. Canonists," in Uta-Renate Blumenthal, ed., Canon Law, Religion, and Politics: "Liber-Amicorum" Robert Somerville (Washington, 2012), 272-83, at 273-4. Nor does this underestimate the significance of the roles played by popes, kings, and magistrates. Cf. Stephen C. Ferruolo, Origins of the University: The Schools of Paris and Their Critics, 1100-1215 (Stanford, 1985), 280-82.

${ }^{12}$ Haskins, Rise of Universities, 8.

${ }^{13} \mathrm{Ibid}$., 8-9. In fact, universitas, collegium, and scola were all general terms signifying such a collective or a guild.
} 
outside authority." ${ }^{\prime 4}$ As we shall see presently, these two types of the guild formation led to further divergence among European universities, diversifying the university's relation to the church and to the state.

With regard to its beginning, then, no pope, king, or emperor founded a university as part of his own dominion. ${ }^{15}$ On the contrary, the effect of the charter was to render the university its own domain of power (studium), distinct from both church (sacerdotium) and state (regium or imperium) ${ }^{16}$ And it was only after the universities proved important nurturing grounds for legal and administrative expertise, much needed for both the church and royal courts, that the ecclesiastical and terrestrial rulers began to establish new universities under their own auspices, sometimes in competition with one another. ${ }^{17}$ Yet even in those instances of imperial or papal founding, studium was recognized as a distinct domain, and never coeval with church or state.

Why did a spontaneous swarming of knowledge seekers and knowledge dispensers take place at this particular moment in multiple locations in the Latin West? Haskins's answer, issued a century ago, has since become his signature concept: the Renaissance of the twelfth century. He postulated that there was a sudden and massive increase in available knowledge at this time, which perforce changed the landscape of institutions of learning. ${ }^{18}$ The headwaters of the new learning were outside the Latin West. As Haskins itemized specifically,

Between 1100 and $1200 \ldots$ there came a great influx of new knowledge into Western Europe, partly through Italy and Sicily, but chiefly through the Arab scholars of Spain-the works of Aristotle, Euclid, Ptolemy, and the Greek physicians, the new arithmetic, and those texts of the Roman law which had lain hidden through the Dark Ages ... This new knowledge burst the bonds of the cathedral and monastery schools and created the learned

\footnotetext{
${ }^{14}$ James A. Brundage, The Medieval Origins of the Legal Profession: Canonists, Civilians, and Courts (Chicago, 2008), 241-2. Stephen Ferruolo, in his conclusion, warns against underestimating the roles played by external authorities, especially in the case of Paris. Ferruolo, Origins of the University, 282-309.

${ }^{15}$ In the case of Oxford, the history of the charter is unusually complicated, and in a sense this university never received a papal bull specifically confirming its status as a studium generale. Cf. Alan B. Cobban, The Medieval English Universities: Oxford and Cambridge to c.1500 (Berkeley, 1990), 43-63.

${ }^{16}$ Cf. Walter Rüegg, "Themes," in Hilde de Ridder-Symoens, ed., A History of the University in Europe, vol. 1, Universities in the Middle Ages (Cambridge, 1992), 3-34, at 4-14; Ferruolo, Origins of the University, 295-315.

${ }^{17}$ The only direct papal founding of enduring significance was the university of the Roman Curia in 1245, in palpable response to the imperial founding of the University of Naples by Frederick II in 1224 . Rüegg, "Themes," 16. Gieysztor suggests that these two universities were "authoritarian establishments not fitting into the general pattern." Aleksander Gieysztor, "Management and Resources," in Ridder-Symoens, A History of the University in Europe, 1: 108-43, at 110-11. Grendler's more recent and comprehensive account shows the two universities generally conforming to the Italian model despite their exceptional origins. Grendler, Universities of the Italian Renaissance, 41-64. Cf. also Paolo Nardi, "Relations with Authority," in Ridder-Symoens, A History of the University in Europe, 1: 77-107, at 86-92.

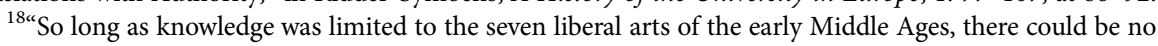
universities, for there was nothing to teach beyond the bare elements of grammar, rhetoric, logic, and the still barer notions of arithmetic, astronomy, geometry, and music, which did duty for an academic curriculum." Haskins, Rise of Universities, 4. Cf. also Charles Homer Haskins, The Renaissance of the Twelfth Century (Cambridge, 1928).
} 
professions; it drew over mountains and across the narrow seas eager youths ... to form in Paris and Bologna those academic gilds [sic] which have given us our first and our best definition of a university, a society of masters and scholars. ${ }^{19}$

The cerebral goods of science and philosophy did not one day set sail on their own accord. Their massive flow came on the back of an enormous expansion of more material kinds of traffic, peaceable as well as bellicose. Beginning in the eleventh century, Western Europe's commercial and political contact with the GreekByzantine-Levantine as well as Arab-'Abbāsid-al-Andalusian culture zones greatly increased. This was also the age of the crusades-part pilgrimage, part warfare, and part trading expedition. In enumerating the remarkable transformations that occurred "from the late eleventh century to the taking of Constantinople by the Latins in 1204," Haskins wrote,

The century begins with the flourishing age of the cathedral schools and closes with the earliest universities already well established at Salerno, Bologna, Paris, Montpellier, and Oxford. It starts with only the bare outlines of the seven liberal arts and ends in possession of the Roman and canon law, the new Aristotle, the new Euclid and Ptolemy, and the Greek and Arabic physicians, thus making possible a new philosophy and a new science. ${ }^{20}$

The year 1204 was the year of the Fourth Crusade, whose pretext-to recapture Jerusalem from the Muslim infidels-was soon abandoned, and resulted in a devastating sacking of Christian Constantinople instead. Thenceforward, the Byzantine Empire never regained the full political power of former times, and some of its learned elites who left the realm in the years to follow went westward, carrying with them books, knowledge, and expertise. ${ }^{21}$ The Latin West in turn went from strength to strength, only to find itself threatened as of the fifteenth century by the rising Ottomans, who were destined to finish off the last remnants of the Roman Empire in 1453, when they took down Constantinople, now to be called Istanbul. Back in the twelfth century, however, the expansion of traffic of the whole Mediterranean region exponentially increased the demand in the West for more robust financial instruments and more sophisticated legal expertise to handle them, all necessary for high-risk commercial enterprises involving travel to faraway places.

The new knowledge from the East and the South was palpably more advanced and systematic, with vastly richer lettered sources; it was something over and above the familiar gamut of traditional instruction hitherto offered in monastic and

\footnotetext{
${ }^{19}$ Haskins, Rise of Universities, 4-5. This cultural transmission was indebted to earlier, centuries-long concerted efforts by the Abbasids to acquire and appropriate the legacies of classical antiquity by translating Greek and other classical texts to Arabic. Cf. Dimitri Gutas, Greek Thought, Arabic Culture: The Graeco-Arabic Translation Movement in Baghdad and Early 'Abbāsid Society (New York, 1998); Amira K. Bennison, The Great Caliphs: The Golden Age of the 'Abbasid Empire (New Haven, 2009), especially 158-214.

${ }^{20}$ Haskins, Renaissance of the Twelfth Century, 6-7.

${ }^{21}$ Cf. Diarmaid MacCulloch, Christianity: The First Three Thousand Years (New York, 2009), 466-502.
} 
cathedral schools of the West. Once the university emerged, the older forms of learning were not entirely abandoned but rather became enmeshed, enhanced, and enlivened by new philosophy and science, and became subsumed as a preliminary stage preparatory to the higher echelon of new sciences. ${ }^{22}$ Thence came the distinction between the lower faculty (liberal arts, all told) and the higher faculties, which came to be consolidated into three: theology, law (subdivided into civil law and canon law), and medicine. ${ }^{23}$

In sum, what began as a voracious importation of Greek-Byzantine and ArabIslamic cultural legacies galvanized the Latins, and their acquisition and assimilation proved so thoroughly successful that they would eventually come to claim the imports as their own. ${ }^{24}$ The consolidation of the appropriated legacies as the very core of "European knowledge" can be traced back to this historic juncture. The new institution, the university, functioned as a vital organ of this transformative process, and in due course it came to be recognized, for good reason, as a quintessentially European institution. ${ }^{25}$

\section{The university and the church}

What, then, was the Latin Church's relation to the third realm of power: the studium? The church had a vested interest in the emerging universities, but not for the purpose of refining its theology or fortifying its doctrinal positions. This much is immediately clear.

Among various domains of new knowledge that caused the university to come into existence, by far the most profoundly consequential for the future of Latin Christendom - and not only for the church - was Roman civil law, rediscovered. ${ }^{26}$ As is well known, Roman jurisprudence was one of the great legacies of the classical Mediterranean civilization. In late antiquity, something of this legal tradition had passed on to the then emerging Christian Church, just at the time Christianity was to become the officially sanctioned religion of the state, and shortly before the political demise of the western half of the empire. The resulting ecclesiastical

\footnotetext{
${ }^{22}$ Cf. Kristeller, "The Curriculum of the Italian Universities."

${ }^{23}$ As we shall see below, this tripartite organization of the higher faculties was specific to the University of Paris and the universities modeled after it. Moreover, the symmetry of the faculties was seldom evidenced in any single institution. In addition to the more specific references already cited see also Astrik L. Gabriel, "Universities," in Joseph K. Strayer, ed., Dictionary of the Middle Ages, vol. 12 (New York, 1988), 282-300.

${ }^{24}$ This also reflects the habitual underestimation of the significance of the Byzantine Empire. For a critical view of this phenomenon see Maria Mavroudi, "Translations from Greek into Latin and Arabic during the Middle Ages: Searching for the Classical Tradition," Speculum 90/1 (2015), 28-59.

${ }^{25}$ Recent scholarship is more inclined to consider the formation of Western Christendom in the context of broader Mediterranean and Near Eastern late antiquity through the Middle Ages, with a greater emphasis on the vital "East-West" confluence. Cf. Peter Brown, The Rise of Western Christendom: Triumphs and Diversity, A.D. 200-1000 (Maldon, 2013), especially "Preface to the Tenth Anniversary Revised Edition," xi-xlvii. In contrast to this trend, Ferruolo, Origins of the University, gives an account of the development of the University of Paris focused almost exclusively on factors internal to Western Europe, or more particularly on the fortuitous circumstances converging in Paris, most importantly the sagacious policies of the Capetian kingdom and its rising capital, and the assemblage of acclaimed masters, above all Peter Abelard.

${ }^{26}$ Cf. Peter Stein, Roman Law in European History (Cambridge, 1999).
} 
law, or canon law, was to be instrumental in shaping the Latin Church's system of governance, but it was not until the twelfth-century Renaissance-when the legendary jurist Gratian systematized canon law for the first time in the West-that it came to acquire its overwhelming significance. ${ }^{27}$ In the political spheres outside the church, on the other hand, the erstwhile imperial legal system had become fragmented and dissipated after the fall of the Western Empire, as it was largely overridden by various tribal customary laws, or so-called "Germanic" or "barbarian laws." This state of decline and dissipation persisted in the West until the aforesaid rediscovery of ius civile (civil law) sometime in the eleventh to twelfth centuries. Meanwhile in the East-that is, in the surviving half of the Roman Empire centered in Constantinople-the governing force of the imperial Roman law had not slackened. The legal corpus continued to be elaborated and brought up to date with full imperial backing; it was first systematized during the reign of Theodosius II in the fifth century, and then more famously by Justinian I in the sixth. It would be hardly an exaggeration to say that the Latin West's discovery of this latter, "Justinian Code" in shorthand, instigated the rise both of the university and of the legal profession, together changing dramatically the very fabric of the sociopolitical organization of the entire region. ${ }^{28}$ The robust growth of the Roman Church at this time was fundamentally and inextricably tied to this dramatic advance in legal culture and expertise. Nor was it a mere coincidence that the first university to come into prominence was Bologna, the center of this revival, which from that point onward became the alma mater of countless bishops, cardinals, and popes. ${ }^{29}$

The circumstance was roughly as follows. The papal court in Rome, no less than princely courts of kings and emperors, was among the greatest beneficiaries of the new breed of legal experts trained in the university. For, by then, the Latin Church, increasingly centralized in Rome, not only held sway over the vast spread of bishoprics and other churchly dominions, but also was gaining the upper hand in relation to the rulers of kingdoms and the nominal imperial order of the West, styled the Holy Roman Empire. ${ }^{30}$ Accordingly, the Latin Church's role increased

\footnotetext{
${ }^{27}$ Colin Morris, The Papal Monarchy: The Western Church from 1050 to 1250 (Oxford, 1989); Anders Winroth, The Making of Gratian's Decretum (Cambridge, 2000). See also Brian Tierney, Religion, Law, and the Growth of Constitutional Thought, 1150-1650 (Cambridge, 1982).

${ }^{28}$ Circumstances of the seemingly precipitous revival of Roman civil law in the Latin West remain obscure. Wolfgang P. Müller argued that it is less likely attributable to a sudden discovery of a longdormant copy of Justinian's Digest somewhere in the vicinity of Bologna, as had been long claimed; rather, evidence suggests a gradual process of recovering and piecing together partial texts over several decades. Wolfgang P. Müller, "The Recovery of Justinian's Digest in the Middle Ages," Bulletin of Medieval Canon Law 20 (1990), 1-29. Cf. also Manlio Bellomo, The Common Legal Past of Europe 1000-1800, trans. Lydia G. Cochrane (Washington, DC, 1995), esp. 112-25.

29" During the pontificate of Alexander III (1159-81) the teaching of law was vigorously encouraged, to the particular advantage of the school in Bologna, which consolidated its position as the most important center in Europe for the study of Roman and canon law ... The Holy See had its own lively interest in promoting the teaching of law, as may be inferred from the great output of canon law rules at the time, and from the appointment to high office of many prelates trained in law." Nardi, "Relations with Authority," 80.

${ }^{30}$ Morris, Papal Monarchy, 387-409. For an efficiently informative account of the transformation of Latin Christendom during this period see Diarmaid MacCulloch, The Reformation: A History (New York, 2004) 26-34.
} 
enormously, as the adjudicator and the final court of appeal for many major suits concerning succession, inheritance, property, and contracts, as well as matters pertaining to the fast-growing business and commercial transactions. A veritable legion of university-trained canon lawyers became the mainstay of church organization. ${ }^{31}$ It stands to reason, then, that the principal concern of the Roman Curia, and the expertise particularly desired and expected from the university, was not liturgical, doctrinal, or theological in nature, but above all juridical and administrative. ${ }^{32}$ The church could never have enough lawyers. Conversely, the Latin Church's institutional maturity helped the emerging university multiply and prosper, not, however, on account of instruction given in theology, but because of the all-important faculty of law. ${ }^{33}$

If this be the principal positive reason why law, and not theology, was the most prestigious faculty of the medieval university, then one could speculate on another aspect of the relative insignificance of theology. For, considering its origin, the university by nature had little to offer in the way of abstract theological ideas or doctrinal designs that would be immediately useful for the Latin Church. After all, the contents of the university curricula, as Haskins's list makes clear, were derived from pagan, infidel, or heretical sources. Be it Aristotle, Galen, Avicenna, Averroes, Maimonides, or some Byzantine, Syriac, or other theologians of Eastern churches, with whom the Latins had had much to quarrel about for centuries, this treasury of wisdom did not speak the language of the Western Church. ${ }^{34}$

This, to be sure, is not to deny that very significant work that we today would call theological was being produced in the Latin West, both during the centuries that used to be called "dark," and at the height of the medieval Renaissances as well. Medievalists today agree, however, that during this period the primary location for deeply metaphysical, devotional, and contemplative activities-if that is what we think theology is-was not the university but the monastic foundations, especially those newly chartered mendicant orders. The first among these was the Cistercians, a group of breakaway reformists emerging from the Benedictine order, who warily kept the university at arm's length. The distance and enmity between the monastic institutions and the emerging university can be seen among the medieval "theologians" themselves. The acrimony is epitomized by the epic confrontation between Bernard of Clairvaux (1090-1153), the towering Cistercian, and Peter Abelard

\footnotetext{
${ }^{31}$ For a detailed account of the development of the legal professionals around this time see Brundage, The Medieval Origins of the Legal Profession, esp. chap. 3-5.

${ }^{32}$ "Everywhere and at every level, a church emerged in the thirteenth and fourteenth centuries which was, in general, legalist in emphasis. The synodal system, fiscalization, and transactions between local churches and the curia all contributed to this general trend and to a growing demand for university graduates." Peter Moraw, "Careers of Graduates," in Ridder-Symoens, A History of the University in Europe, 1: $244-79$, at 253 .

${ }^{33}$ Brundage, The Medieval Origins of the Legal Profession, 78-80.

${ }^{34}$ It may be remembered in this context that, from the beginning of the imperial patronage of Christianity in the early fourth century, churches of West and East quarreled over many things and for many centuries, and during much of the time the Church of Rome was an outlier, peripheral to the powerful and more populous churches in Antioch, Alexandria, Carthage, Constantinople, etc. The disagreements and animosity finally boiled over in 1059 , resulting in the Great (East-West) Schism.
} 
(c.1079-1142), the paragon of the university theologian avant la lettre. ${ }^{35}$ A century or more later, when the erstwhile Greco-Arabic resources (Aristotelian logic in particular) finally began to do some serious work for theology in the university-thus leading to the formation of the first bona fide academic theology, or scholasticismmuch of the production was concentrated in Paris and Oxford, and still later in some other northern universities modeled after Paris. ${ }^{36}$ As a rule, these northern universities came to be closely, though sometimes contentiously, associated with some of the new mendicant foundations, such as the Franciscans, the Dominicans, and the Augustinians, and still later the Jesuits. ${ }^{37}$

An altogether different condition obtained in the Italian universities. As Paul Oskar Kristeller memorably noted nearly half a century ago, in Italy theology was not taught within the university at all. ${ }^{38}$ More recently Paul Grendler has documented in great detail how theology never gained much foothold in any of the Italian universities. And if it did, it was just that: a bit of extraterritoriality granted to an outside entity wedged into an institution foreign to it. In sum, according to Grendler, "Theology arrived late, had few instructors, and remained peripheral to the main purposes of the university." It was actually mendicant orders of one sort or another, "located in university towns but separate from the university," that did the duty of teaching theology, mainly to their own kind. Gradually, limited incorporation of theology into the university curricula took place when "one or two friars" from the mendicant schools began to be appointed to theological professorships. Even so, the faculty of theology remained "a kind of confederation of the studia monastica under the name of the civic university but with limited participation by the latter"; on the whole, "other members of the university community did not respect" the theologians. ${ }^{39}$ In medieval Italy, then, theology alone, and no other discipline, had this exceptional status and this anomalous history of incomplete integration into the university, and theology never outgrew the fundamental alienness of its origin. ${ }^{40}$

Why this should have been so, one could state first, following Kristeller, that Italian universities began as schools of law and medicine, not of theology. But

\footnotetext{
${ }^{35}$ Alex J. Novikoff, "Peter Abelard and Disputation: A Reexamination," Rhetorica 32/4 (2014), 323-47; Constant J. Mews, "The Council of Sense (1141): Abelard, Bernard, and the Fear of Social Upheaval," Speculum 77/2 (2002), 342-82; Ferruolo, Origins of the University, 47-66.

${ }^{36}$ See the next section below.

${ }^{37}$ Morris, Papal Monarchy, 358-66; Monika Asztalos, "The Faculty of Theology," in Ridder-Symoens, A History of the University in Europe, 1: 409-41, at 414-17; Paul F. Grendler, The Jesuits and Italian Universities 1548-1773 (Washington, DC, 2017).

${ }^{38}$ “ $T$ There were no faculties of theology there, and the occasional presence of a course or professor of theology indicated a temporary arrangement and an optional course for arts students, not a program of studies fit to prepare professional theologians." Paul Oskar Kristeller, "Thomism and the Italian Thought of the Renaissance" (1974), in Medieval Aspects of Renaissance Learning (New York, 1992), 29-91, at 43-4. See also Kristeller, "The Curriculum of the Italian Universities."

${ }^{39}$ Grendler, The Universities of the Italian Renaissance, 353-92, esp. 357, 387. The way in which theology became gradually integrated into the university is similar to the way departments of religious studies in many American colleges first began by recruiting personnel from nonteaching staff: typically, a college chaplain, a local rabbi, and other available adjuncts deemed knowledgeable enough to teach "religion."

${ }^{40}$ John Monfasani, "Aristotelians, Platonists, and the Missing Ockhamists: Philosophical Liberty in Pre-Reformation Italy," Renaissance Quarterly 46/2 (1993), 247-76, at 252-6.
} 
this should be couched in a broader question: how would any university begin otherwise, given its general origin story as described above? To our detriment, this is a question seldom asked. Today, the story of Italian universities seems to us merely eccentric, not normative. This is no doubt because we have been accustomed to thinking of the medieval university according to another model, namely Paris. But if we are to consider the matter more historically, it is not the oddity of Bologna that needs an explanation. ${ }^{41}$ On the contrary, what calls for accounting is, first, how Paris turned into something so exceptionally different and, second, how Paris and its northern offspring came to dominate our imagination when we call to mind "the medieval university." Addressing the second of these questions seriously would require a historical investigation of a much larger scope than the present occasion would allow. In the remainder of this article, I aim to delineate some of the factors that made Paris distinct from the universities in the South.

\section{North and South}

While the seat of the Latin Church was officially still in Rome, another center of the medieval Latin civilization lay farther to the northwest. Paris, the royal seat of the kingdom of France, developed a distinct power base most recently under Capetian rule, with a sociocultural complexion measurably different from the cities flourishing in the South oriented toward the Mediterranean. With a robust religio-clerical ethos of its own, situated in a locale less exposed to the currents flowing from the East and South, Paris and the surrounding region of northern France turned into an alternative sphere of influence, increasingly more dominant. Already in the early decades of the twelfth century, renowned logician-theologian-metaphysicians of the day-Peter Abelard, Peter Lombard, and Hugh of Saint Victor among them-were offering instruction at several schools housed in the cathedral and various abbeys in the city, attracting students from all over the Latin world. Paris of the twelfth century was no doubt an unparalleled dispensary of cutting-edge philosophy of this description, and this expertise in particular came to constitute a kernel of the university. It would go on to become the defining feature of Paris in the centuries to come. ${ }^{42}$ This distinctly Parisian profile of the university soon traveled still farther north to the British Isles and took root in Oxford, England, and shortly thereafter in Cambridge.

This well-known chronicle should not lead us to conjecture, however, that it was inevitably theology that initiated the emergence of the university at Paris, or that the preeminence of the theological faculty in Paris was unchallenged throughout its history. Nor is it warranted to imagine that this university in its formative

\footnotetext{
${ }^{41}$ Henry Malden notes a few other noteworthy characteristics of Bologna-largely crediting Savigny for the information-such as early establishment of salaried professorships and significant presence of women on the faculty teaching mathematics, natural philosophy, Greek, and anatomy. Henry Malden, On the Origin of Universities and Academical Degrees (London, 1835), 60-61, 63-4. Cf. Friedrich Carl von Savigny, Geschichte des Römischen Rechts im Mittelalter, vol. 3 (Heidelberg, 1822).

42" Paris, along with its very advanced and differentiated urban society, was at the center of the early history of the university in the northern half of 'older' Europe in the twelfth and thirteenth centuries. Despite numerous personal contacts, however, the world of its studies was basically different from that of northern Italy ... The church milieu in the broadest sense was more important." Moraw, "Careers of Graduates," 248-9.
} 
years was unaffected by the historical dynamics that brought other universities in the south into existence. Indeed, once the university began to take shape in Paris, it appears to have exhibited much the same tendency as everywhere else, most notably a surge in the number of law students, so much so that, Brundage reports, "by the 1170s and 1180s, people were beginning to complain that law was gaining ascendency at Paris and Oxford as well." "Whoever those "people" were, the source of their complaint undoubtedly was the fact that a torrent of able young men were seeking university training in law in the hopes of taking up the abundant opportunities for lucrative legal practice, especially in civil and commercial spheres, instead of entering into the service of the church. This, above all, was irksome to the church.

Nothing testifies to this contemporary reality more clearly than the preemptive measure Pope Honorius III took in 1219, in an apparent attempt to stop this medieval brain drain. The bull he issued, called Super Specula, prohibited any instruction in civil law at the University of Paris; it also forbade the same "in several cities in the vicinity," at the pain of excommunication by the local bishops, and also at the cost of being "excluded from participating as an advocate in the ecclesiastical courts for a while."4

Did the Pope intend to promote theology by suppressing law? Or did he rather want more canonists to be graduating, and fewer civilians? Today's medievalists tend to say that his motives are debatable. ${ }^{45}$ The bull itself mentions as its rationale, first, that "laymen in France and several other provinces do not use the [secular] laws of the emperors," and second, that there is hardly any law case that cannot be resolved by the ecclesiastical court. This seems to suggest that it was all about law, about jurisdiction. The underlying argument may amount to this: knowledge of civil law is unnecessary in France because the kingdom of France is not ruled by imperial law (since it lies outside the Holy Roman Empire), and because canon law can (and should) adjudicate everything in the realm. ${ }^{46}$ But if such was the basic thrust of this bull, the Pope's strategy was disastrously shortsighted, and bound to fail.

The papal interdiction specifically targeted the faculty of civil law, but the law as a whole, civilian and canonist alike, was negatively affected at Paris. For, as Brundage explains, "notwithstanding Honorius III's curious claim to the contrary," instruction in canon law without civil law was at best seriously deficient because "canon law and Roman law depended on one another both intellectually and institutionally." ${ }^{47}$ Aspiring law students presumably understood this quite well, so they shunned Paris and flocked to the school in nearby Orleans instead, causing the Paris law faculty to contract precipitously. The school in Orleans, in turn, quickly attained university status and, for all intents and purposes, turned into a satellitecampus law school of the University of Paris. ${ }^{48}$ Indeed, Orleans's meteoric rise was

\footnotetext{
${ }^{43}$ Brundage, The Medieval Origins of the Legal Profession, 245.

${ }^{44}$ Super Specula as cited in Decratals of Gregory IV (1240), http://legalhistorysources.com/Law508/ SuperSpeculum.htm (accessed 25 July 2019).

${ }^{45}$ Cf. Asztalos, "Faculty of Theology," 413.

${ }^{46}$ This would be a questionable argument at best, if implied here at all, but it might help justify Honorius's prohibition aimed at Paris and France while he would not attempt to do the same elsewhere, within the Holy Roman Empire.

${ }^{47}$ Brundage, "Medieval Battle of the Faculties," 279.

${ }^{48}$ Gieysztor, "Management and Resources," 111.
} 
such that, within a matter of a few decades, it became "a serious rival of Bologna." This turn of events is yet another indication that Honorius's decree failed to achieve even its explicitly stated purpose, namely that instruction in civil law should be prohibited not only in Paris but also in "other cities or places nearby." And even in Paris, the ban on teaching civil law apparently could never be fully implemented. In any event, a succession of popes that followed Honorius had effectively dismantled his policy by the century's end. ${ }^{49}$

Despite its general failure and backpedaling, the papal order of 1219 had a lasting consequence for the University of Paris. Whether or not some theologians initially had a hand in Honorius's action, as some historians suspect, Paris theologians had reason for new optimism in the wake of the bull. ${ }^{50}$ The atrophy of the law faculty allowed the theological faculty to be ever more prominent, and Paris became unusual among medieval universities in that the law faculty did not claim a numerical majority. ${ }^{51}$ And in this sense at least, this turn of events benefited the theologians. At the same time, this also meant that the Roman Curia had an especial reason to be vigilant in monitoring the activities of the masters and scholars at the University of Paris, which, for that reason, "was far more tightly linked to the church than Bologna," or anywhere else. ${ }^{52}$

Several conditions made Paris particularly vulnerable to direct ecclesiastical meddling in university affairs. The most fundamental among them was, again, the very presence of the prominent theological faculty itself. To put this in perspective, it is useful to consider the general layout of academic specialization in the universities at the time, described here by Brundage:

Every medieval university offered degrees in canon law. Because some acquaintance with Roman law was essential for canonists, moreover, most universities provided some teaching in Roman law, although not all offered degrees in it. Nearly all universities taught the liberal arts and many could boast a medical faculty as well. Very few, however, offered organized teaching in theology: Paris, Oxford, and Cambridge were the only universities authorized to confer theology degrees before $1300 .^{53}$

The only office that could authorize a theological faculty was the church, and the sharply limited number of the universities with an accredited theology faculty

\footnotetext{
${ }^{49}$ Brundage, The Medieval Origins of the Legal Profession, 232-4.

${ }^{50}$ Honorius's immediate predecessor, Pope Innocent III (r. 1198-1216) - who had studied theology at Paris and for some years read law at Bologna-appointed an English-born master of theology at Paris, Robert of Courson, as his legate to France, whose tasks included, among other things, preaching crusades and writing the first extant statutes for the University of Paris in 1215. Ferruolo, Origins of the University, $300-5$.

${ }^{51}$ According to Brundage, The Medieval Origins of the Legal Profession, 232, at every French university other than Paris, "the schools of law were significantly larger, more prestigious, and better attended than other faculties" throughout the thirteenth century. Brundage also notes elsewhere in the same volume (ibid., 268) that, at the end of the fourteenth century, an astonishing 83 percent of students at Avignon were studying law and 64 percent at Toulouse, though somewhat fewer in universities in northern France, at 39 percent on average, and still fewer in German universities, at 14 percent.

${ }^{52}$ Ibid., 234.

${ }^{53}$ Ibid., 244.
} 
almost certainly reflected the church's interest in keeping a tight rein on what was to be professed, learned, and publicly disseminated. No compelling evidence seems to have surfaced, in any case, suggesting that the Roman Curia was interested in proliferating degree-granting theology faculties, or bolstering the size of the already existing ones. On the contrary, the primary concerns were unmistakably in the direction of containment, quality control, and, no doubt, enforcing compliance. ${ }^{54}$

In effect, in medieval times, doctorates in theology were rare. It is plausible, perhaps very likely, that some Parisian theologians were eager to claim this rarity and exclusivity as a mark of distinction and superiority; and, in view of the long and arduous course of study prescribed for theological doctorates at Paris, such a claim would not be entirely without merit. ${ }^{55}$ On the other hand, if lawyers were legion, fast-moving, and ubiquitous, they seemed no worse off for that. Their employment opportunities were nearly endless, and on the whole both canonists and civilians were well placed, well paid, and many of them powerfully positioned. ${ }^{56}$ And they were a multitude. So the sheer numbers were against the coterie of rarified "speculative theologians," just as, in reality, the practical exigencies of running the church organization-no less than the business of running the state-gained the upper hand and overwhelmed such ideals as apostolic poverty, contemplative quietude, cure of the soul, and the like. ${ }^{57}$

What was more, those speculative theologians were far more likely to be in a precarious position, treading the uncertain boundaries of correct church doctrines at every new scholarly pronouncement, whereas canonists-styled "practical theologians"-enjoyed much greater leeway in their academic pursuits, pushing the envelope in all directions. ${ }^{58}$ It is, of course, not surprising that theologians were more liable to meet ecclesiastical censure than their colleagues in other faculties, who could conceivably be, but rarely were, in trouble with the church on account of something inferred from their medical or legal theories. For theologians, the heavy hand of the church hovering over them was an occupational hazard, and it requires no imagination to understand why universities celebrated for their

\footnotetext{
${ }^{54}$ According to Ferruolo, Origins of the University, 294, in 1207 Pope Innocent III ordered the bishop of Paris "to restrict the number of masters actively teaching theology to no more than eight," on the ground that "Paris ... should have enough theological masters to provide for the needs of the Church but not so many that regard for the office of theologian would be lessened and instruction unskillfully discharged."

${ }^{55}$ One such example was Gerald of Wales (1146-1223), whose self-aggrandizing autobiography is described extensively in Ferruolo, Origins of the University, 168-83. Regarding the course of theological studies at Paris in the late medieval to early modern period see James K. Farge, Orthodoxy and Reform in Early Reformation France: The Faculty of Theology of Paris, 1500-1543 (Leiden, 1985), 13-28.

${ }^{56}$ Brundage, The Medieval Origins of the Legal Profession, 344-8.

57"In the practical life of the church, men of the canons eventually prevailed in numbers, preference, and influence-so much so that the carping later from theologians arose as much from rivalry or envy as from principle." John van Engen, "From Practical Theology to Divine Law: The Work and Mind of Medieval Canonists," in Proceedings of the Ninth International Congress of Medieval Canon Law Munich, Monumenta Iuris Canonici, Series C. Subsidia (Vatican City, 1997), 873-96, at 877-8.

58"Canonists explored and developed novel ideas about such basic issues as natural rights, representation and consent, the corporate structure of ecclesiastical and civil government, the right to wage war, or limits on the authority of popes, bishops, and cardinals, or even monarchs, more freely than their colleagues in the theological faculty could entertain novel hypotheses about such matters as the Trinity, the Eucharist, free will, or apostolic poverty." Brundage, The Medieval Origins of the Legal Profession, 467.
} 
theological faculty, such as Paris and Oxford, should be tightly in the grip of the authorities, both of the state and of the church. ${ }^{59}$

Exceptional though Paris was, there were some important institutional features that originated there and subsequently spread to many other universities, particularly in the North, beginning in the thirteenth century. One such innovation of considerable significance was the very idea, the term, and the structure of academic faculties. ${ }^{60}$

Following the customary practice in today's scholarship, and also for the reason of expediency, I have been employing the term faculty to refer to each of the distinct units or fields of academic study, or discipline. This conventional use of the termthe first documented instance of the term facultas used in relation to the university is said to be in the thirteenth century or possibly earlier ${ }^{61}$-might impart an impression that the oft-repeated list of four faculties, comprising one lower and three higher faculties, was an all but preordained structure of the emerging university everywhere. On the strength of this suggestion, moreover, it is sometimes asserted-evidently based on an erroneous assumption that university had something to do with the universality of knowledge-that a university by definition must be outfitted with most if not all of these fields of study. ${ }^{62}$ But that is not how the university began. Historians of the medieval university appear to be in general agreement that the quadripartite organization of the masters' guild-wherein each of the four faculties exercised the right to self-govern, set curricular standards, confer degrees, etc.- originated in Paris and nowhere else, and that this organizational structure was variously adopted by the universities established later in Northwestern and Central Europe. ${ }^{63}$

\footnotetext{
${ }^{59}$ Citing the eighteenth-century documentation by Duplessy d'Argentre, Monfasani, "Aristotelians, Platonists, and the Missing Ockhamists," 252-3, notes an extraordinary number of cases censuring university theology professors at Paris and Oxford, compared to none whatsoever in the Italian universities before the Reformation, for the obvious reason that there were no structurally comparable theology faculties in the Italian universities.

${ }^{60}$ Another highly consequential innovation was the development of residential colleges. As I aim to argue in a larger study, these features, both of which originated in Paris, had the effect of rendering ecclesiastical supervision of the university more efficient-though through quite different paths-thus causing the university's relation to the church and to the state to take on a particularly symbiotic, collusive character.

${ }^{61}$ Brundage, The Medieval Origins of the Legal Profession, 247, suggests that the first documented instance of the term facultas as an organizational principal within the university dates back to midthirteenth century. McGinn, on the other hand, notes that the phrase facultas theologiae at least appeared earlier in the writing of Alan of Lille (1128-1202). Bernard McGinn, "Regina quondam ...," Speculum 83/4 (2008) $817-39$, at 818 .

${ }^{62}$ This groundless argument was used in the decades-long British parliamentary quarrels in the early nineteenth century by those opposing the accreditation of the University of London, on the ground that it was not to have a faculty of theology. The error was pointed out as early as 1835 by Henry Malden, On the Origin of Universities, 12-14. But this did not stop Cardinal Newman in the 1850s from insisting on this idea. John Henry Newman, The Idea of a University, ed. Frank M. Turner (New Haven, 1996), 25.

${ }^{63}$ Gieysztor, "Management and Resources," 111-12, explicitly states that the model of the four faculties originated in Paris. "It consisted of one lower faculty, arts, and three higher faculties, theology, law, and medicine. (After Pope Honorius III forbade the teaching of civil law in Paris in 1219, the law faculty taught only canon law-University of Orléans can be considered as the civil law faculty of the Paris studium.)"
} 
Southern universities, epitomized by Bologna, were differently constituted. Unlike Paris, Bologna emerged as a guild of scholars (i.e. students); therefore the difference between Paris and Bologna was not only about how the disciplines were demarcated. To be more precise, we should say, here borrowing the words of Aleksander Gieysztor, that Bologna was actually "a cluster of universities, each for students of only one discipline." There were two such disciplines, namely "the universitas legistarum, which can be called the law faculty, and the universitas artistarum et medicorum (faculty of arts and medicine)." Each of these student universities was further divided into two "nations" (nationes), one "each for students of a particular geographical origin," the Alps being the dividing line. ${ }^{64}$ Furthermore, masters (i.e. professors) had their own corporation "completely distinct" from those of the students, and each of these professorial corporations was also specific to a discipline, and was called collegium doctorum, or "college of doctors." This professorial collegium-not to be confused with the residential college-effectively corresponded to "faculty" of the Parisian system; each collegium was empowered to set academic standards and to confer degrees and licenses.

Whatever the extent of the analogy or affinity between the French faculties and the Italian collegia, there is no denying that Bologna's studium as a whole had a strikingly composite character, in contrast to the streamlined system tending toward centralization that is characteristic of Paris. And it is this composite constitution of the university system as a whole that goes some distance in explaining how instruction in theology in Italian universities could be maintained in an ad hoc manner, occupying an extraneous position throughout the Middle Ages, and even well beyond. In short, in Bologna, theology teaching was conducted within the city or its vicinity, but outside the university, only tangentially associated with the new institution.

Whence comes this structural difference between Paris and Bologna as regards the position and status of theology? It may be remembered here that, in the South and the North alike, the intellectual enterprise that we today call theology had long been carried out in monastic institutions and, especially since the twelfth century, by mendicant orders. "Teaching of theology" in this broad sense preexisted the advent of the university, and for the most part it continued to thrive outside the university. When the university corporations were forming in Paris-predictably, it was the law faculty that was the first to organize itself-those mendicant teachers of theology around the city, too, began to form a guild. By the time the first extant university statutes of Paris were being drawn up (1215), ${ }^{65}$ theology had already established itself as one of the four disciplines, or faculties.

This, however, did not happen elsewhere. In all other early universities-again, with the notable exception of Oxford and Cambridge, both of which are said to have been directly influenced by Paris - theology never worked its way into the university system in the formative years as it did in Paris. In Bologna, as we have seen

\footnotetext{
${ }^{64}$ Gieysztor, "Management and Resources," 109-10. Groupings in terms of the place of nativity _ "nations" in the older sense-also existed in Paris, though naturally the divisions were differently configured: French, Picard, Norman, and English (later to be called English-German). Gabriel, "Universities," 283-4.

${ }^{65}$ Ferruolo, Origins of the University, 300-1.
} 
above, there emerged not four but two disciplines: law on one hand, and arts and medicine on the other, each of these disciplines comprising a guild of students and a guild of teachers. In this bicameral constitution of the university at Bologna, there was no place for theology. The teaching of theology conducted in the city of Bologna or in the nearby monasteries did not become integrated into the university. This outcome is not altogether surprising.

To begin, unlike law students or arts and medicine students, who formed their own respective universitas, the students of theology had no corporate body to represent them, hence no rector could be elected by them. Instead, their identity remained tied to one or the other of the mendicant orders to which most of them belonged, just as their teachers did. Furthermore, even though theology students could be granted a doctoral degree at the completion of their studies by the authority of the collegium doctorum of theology, this latter body-which had the power equivalent to the collegia of the other two disciplines-was not a guild of teachers of theology. Instead, the theological collegium was composed of learned townsmen who presumably had done some advanced study of the subject somewhere and thus were considered qualified to exercise this power. This collegium might include some of the teachers, but it was not coextensive with a teachers' collective, and it almost certainly included religious officeholders. In short, in the Italianate universities, theology had neither a scholars' guild nor a masters' guild. Instruction was given by monks and friars in their own premises to young men mostly destined for the same career; their doctorates were not conferred by a professoriate. All in all, teachers and students of theology were all but invisible. The situation did not significantly change even after "one or two friars" were appointed to professorships in the university, as happened in some of the Italian universities. ${ }^{66}$

This seems to amply justify Kristeller's statement that the medieval Italian university did not teach theology. For this reason, it might be reasonable to suggest that Bologna and many of the southern universities retained the original character of the university as an institution to foster new knowledge of foreign origin, whereas in Paris an infusion of the more native-grown monastic and mendicant traditions into the newly emerging university occurred at a very early stage, and theology thus became an integral part of the institution as one of its faculties.

The Paris-Oxford-Cambridge monopoly of doctorates in theology began to erode in the fourteenth century, when the relation between the papacy and the French crown seriously soured, and the political supremacy that the Roman Curia had enjoyed in the preceding centuries-often dubbed papal monarchy-steeply declined. During the century of the Avignon papacy that followed (1309-76), a succession of seven French popes, all with French royal backing, chose to establish the papal court at Avignon, a city far to the west of Rome but still a satellite papal territory and outside the domain of the French kingdom at the time. After the seventh

\footnotetext{
${ }^{66}$ Information detailed in this and the preceding three paragraphs is comprehensively discussed in Grendler, Universities of the Italian Renaissance, Ch. 10. Cf. also Kristeller, "Curriculum of the Italian Universities," 85-7; Gieysztor, "Management and Resources."
} 
Avignon pope returned to Rome and died soon thereafter in 1378, the situation only got worse, as it commenced another half-century of divided papacy (13781437), this time with two rival popes (or, technically, a pope and an antipope) between the two cities. All the while, much of the western half of the Latin world was embroiled in incessant warfare, roundly called the "Hundred Years War," which lasted until the mid-fifteenth century. The result, as we know, was the territorial consolidation of France by the triumphant House of Valois and its allies, and in turn the retreat from the Continent (excepting Calais) of the erstwhile French Norman Plantagenets, who thenceforward would become, willy-nilly, English. ${ }^{67}$

The end of the Paris-Oxbridge monopoly on theological doctorates was part of the fallout of this prolonged political turmoil. The papal court-with its hold on universal Latin Christendom now unsteady, and the political fortune of the city of Paris itself unpredictable-began to charter new degree-granting theological faculties elsewhere. Just around this time, entirely new universities were being established one after another, especially in the German lands, mobilized mainly by the interests of various regional rulers, and facilitated in no small part by the "exodus of scholars" from Paris. ${ }^{68}$ At this point in time, the state's control over the university became acutely constrictive at Paris, especially after 1452 when a "general reform" of the university's statutes was effected at the instigation of the French crown. The same change was occurring elsewhere in France. "Henceforth," observes Paolo Nardi, "France tended to restrict drastically the immunities and privileges which the academics of the twelfth to fourteenth centuries had enjoyed before the complete consolidation of the French monarchy." ${ }^{69}$ This, in effect, was the beginning of the end of the medieval university, studium, the third realm of power, distinct and free from both regium/imperium and sacerdotium. The final demise came a century later, when the nominal catholicity of Latin Christendom was permanently lost in the wake of the Protestant Reformation. As for the theology faculty of the University of Paris, from this point onward it famously held on to a hardline position on the side of the absolutist state and its repressive religious policies, until, that is, it met the ire of the Republican revolutionaries in the late eighteenth century, followed by Napoleon who swiftly moved to dismantle the university as a bastion of Ancien Régime. ${ }^{70}$

\section{Conclusion}

The profile of the medieval university that emerges from the foregoing sketches looks markedly different from the image of a religion-saturated institution where theology was the overlord. With a few exceptions-three, to be exact-theology hardly had a normalized existence in the universities during the first two centuries of the institution's vigorous growth and flowering. This also means that the robust

\footnotetext{
${ }^{67}$ Norman Davies, The Isles: A History (Oxford, 1999), 405-39.

${ }^{68}$ Asztalos, "Faculty of Theology," 435-6.

${ }^{69}$ Nardi, "Relations with Authority," 104.

${ }^{70}$ Cf. Notker Hammerstein, "Relations with Authority," in Hilde de Ridder-Symoens, A History of the University in Europe, vol. 2, Universities in Early Modern Europe (1500-1800) (Cambridge, 1996), 11353 , at $124-9$.
} 
ascendency of the Latin Church that was taking place in the same period did not occasion a surge in eminence or popularity of theology as an academic enterprise. But it certainly caused the value and the prestige of canon law to skyrocket. Clearly, theologians did not like this. If the masters and scholars of other faculties had little respect for them, Paris theologians at least were not too shy to come back and hurl insults in return, targeting particularly the lawyers, whom they feigned to disdain as government's pawns, "political idiots," and "asses." ${ }^{\text {"1 }}$ In their turn, the lawyers, however self-confident in their manifest worth, could not be relied upon to remain preternaturally above academic jousting of this sort. Ample contemporary evidence tells of some powerfully stationed canonists testily chiding the theologians, putting them in their place. $^{72}$

In view of these facts, the stock phrase we habitually revert to in characterizing theology's station in the medieval university, where it is supposed to have been "the queen of the sciences," is positively strange. Was this airy sobriquet but a nearempty phrase we dutifully intone time and again out of some displaced deference to religion, which we imagine to have epitomized Europe's premodern past? Or have we perhaps taken too much at face value some medieval theologians' wishful thinking, their doleful self-promotion, assigned as they were in reality to their frayed seats? Or worse yet, have we been taken in by some early modern screed dogmatically proclaiming the absolute supremacy of the theological to all eternity?

It has been often suggested that Thomas Aquinas (1225-74) coined the phrase, regina scientiarum, honoring the dignity of theologia. But the attribution appears to be inaccurate. ${ }^{73}$ Thomas, it is true, reportedly said that "philosophy and other sciences" were ancillae, meaning, literally, handmaids. Moreover, his contemporary and another Paris-educated theologian, Bonaventure (1221-74), similarly opined that "all branches of knowledge serve theology." But this does not mean that others agreed with the theologians; certainly not in Bologna or Padua, and probably not in Paris either. And nothing that we have seen suggests that the masters and scholars of those "ancillary" sciences thought of themselves as rendering their service from the subservient position that the theologians rhetorically allotted to them. In fact, all this seems to be no more than a figure of speech, or jargon internal to the theology faculty at that. Gerald of Wales (1146-1223), for example, is remembered not only for his penchant for boasting his improbably high-flying academic career, but also for having expressed his ideal of scholarly acquirements in the following picturesque terms: "upon the foundation of arts and letters, to raise high the walls of civil and canon law and above them to complete the sacred roof of theological learning." ${ }^{74}$

Call it a queen or a rooftop, the high station thus accorded to theology was largely symbolic and, in fact, contrary to the material condition on the ground.

\footnotetext{
${ }^{71} J a c q u e s$ Krynen, "Les légalistes 'idiots politiques': Sur l'hostilité des théologiens à l'égard des juristes, en France, au temps de Charles V," in Théologie et droit dans la science politiques de l'état moderne (Rome, 1991), 171-98; Brundage, "Medieval Battle of the Faculties," 279-80.

${ }^{72}$ Van Engen, "From Practical Theology to Divine Law," 878, relates how the future Pope Boniface VIII, "while still cardinal and canonist," publicly chastised Paris masters of theology for "acting foolishly" and warned against imagining that "Christ ruled by their [theologians'] arguments."

${ }^{73}$ McGinn, "Regina quondam ...," 817-19.

${ }^{74}$ Quoted in Ferruolo, Origins of the University, 170.
} 
Though the rhetoric remained thus aloft, beginning with Alan of Lille (11281202?) - who spoke of the "regal prerogative" of the theological faculty, but as an ideal yet unrealized-these regal references by the eminent Paris theologians were always couched in lament, as they decried the other faculties' neglect and their insolent disregard of the divine hierarchy. All of this leads the modern historian Bernard McGinn to observe summarily, "the role of theology in the history of Christianity, and even in the medieval universities, was never quite as imperial, as powerful, and as settled as we might be inclined to think." 75

Wherever the true origin of the phrase may lie, "the queen of the sciences" was not really a medieval problem, when the phrase had little or no currency. But it is a problem for us to turn over and to scrutinize, to ascertain its worth and its function among us. To understand how we got here, and how we have become nearly incapable of thinking beyond the Paris model of the medieval university-this will require historical study of much broader scope. At the threshold of any future investigation to that end, surrendering the idolatry of this imaginary queen may be entirely salutary.

For now, let it suffice to note that, insofar as the foregoing sketches of the early history of the university could attest, the relation between theological learning and the university was, for the most part, tangential. It might be fair to say that they coexisted adjacent to one another, intellectually as well as institutionally, with varying degrees of integration and with different styles of cooperation, depending on the circumstance of each locality. In any event, there is no evidence to suggest that the theology faculty ever functioned as a regular legislator of an overarching framework or as a dispenser of spiritual "worldviews" that organized or dictated the order of knowledge in the medieval university.

A very significant change to this temporizing relation between theology and the university did take place toward the end of the Middle Ages, it is true, when there was a sudden proliferation of theology faculties all over the Latin West, owing to the historical circumstances briefly described in the previous section. And from this point onward, the theology faculty became a regular feature, more or less, both in the newly established universities and in the already existing ones. The rate of growth and empowerment of theology accelerated even more during the Protestant Reformation, when numerous new universities came to be founded by correspondingly numerous territorial rulers of the now confessionally fractured Latin Christendom, particularly in the North. Naturally, each of these rulers would ensure the university's and its inmates' conformity to his own confessional persuasion, and the theology faculty became the principal organ for the regulatory purpose. ${ }^{76}$ Meanwhile, in the regions where churches remained obedient to Rome,

\footnotetext{
${ }^{75}$ McGinn, “Regina quondam ...," 817-18.

${ }^{76}$ These conditions, prior to the onset of university reforms of the nineteenth century, are usefully described in Thomas Albert Howard, Protestant Theology and the Making of the Modern German University (Oxford, 2006). Cf. also Charles E. McClelland, State, Society, and University in Germany 1700-1914 (Cambridge, 1980).
} 
some new religious orders-above all the Jesuits-worked assiduously to institute a theology faculty in as many universities within their domain of power, expressly to be a bulwark against the scholarly challenges from the Protestant sectaries. ${ }^{77}$ As a result, in both North and South, there came a dramatic increase in church and state control over university affairs.

It was these early modern, post-Reformation conditions of the university that gave prominent intellectuals of the eighteenth century-Leibniz and Kant among them-much to complain about. For instance, in recollecting his desultory teenage years at Magdalen College, Oxford, Edward Gibbon-himself less a reform advocate than a happy transplant in Calvinist Geneva as a religiously noncommittal foreigner-had this to say:

The schools of Oxford and Cambridge were founded in a dark age of false and barbarous science, and they are still tainted with the vices of their origin. Their primitive discipline was adapted to the education of priests and monks, and the government still remains in the hands of the clergy, an order of men whose manners are remote from the present world, and whose eyes are dazzled by the light of philosophy. The legal incorporation of these societies by the charters of popes and kings had given them a monopoly of the public instruction, and the spirit of monopolists is narrow, lazy, and oppressive. ${ }^{78}$

This vituperative judgment by the mature Gibbon was just one example of the imperious profile of the theology faculty reflected in the minds of the university critics of the Enlightenment era. This profile was projected backward in time, all the way to the Middle Ages, and this phantom theology has since grown to a monstrous proportion, an image formidable enough to cast a long shadow even to this day. Thus it came about that the medieval theology faculty finally achieved a posthumous fame, though not as a crowning pinnacle of universal knowledge, but as a senescent despot long overdue for an overthrow.

History of religion(s) as something distinct, separate, and other than theology-or, as a bona fide science of religion in contradistinction to the fideistic ratiocinations predicated on revealed truths, as some would have it-this has been a self-assigned defining mark of the academic study of religion for over a century. At the same time, it has long been thought that this new science has been struggling to emerge, in order to become itself, in the long shadow of theology, both institutionally and theoretically, and perhaps temperamentally as well. But this shadow of the past is just that: a backward projection, an overblown shade of something that was not quite what has been imagined. Besides, the genealogy of the modern study of

\footnotetext{
${ }^{77}$ In another important study, Grendler documents the Jesuits' activism in this regard, their generally limited results in the Italian universities, contrasted with dramatic successes in the German lands. Grendler, The Jesuits and Italian Universities.

${ }^{78}$ Edward Gibbon, Memoirs of My Life and Writings, ed. Oliver Farrar Emerson (Boston, 1898; first published 1796), 48.
} 
religion, all told, is actually quite heterogeneous, and the lineage is therefore much more complex, and its legacy highly debatable. ${ }^{79}$

Meanwhile, probably owing to the very nature of the field and its chronic condition of hyper-self-consciousness since the last century, historians of religion by and large are uncomfortably aware of the inexorable ambiguity, volatility, and indeterminacy of what is meant by "theology," "religion," and, for that matter, "history"; so much so that there often lurks a measure of reticence when it comes to delineating explicitly the difference between theology and religious studies, and, even more, owning the difference. To be sure, discomfiture or hesitancy in itself may not lead to any useful insight. And it is premature, moreover, to expect that the case of "religious studies" could be a synecdochic miniature model that would point to some broader general truths about the secularization of learning, or about the birth of human sciences out of, and away from, providential cosmologies. That said, this much may still be true: few other modern sciences have worried as much, and for as long, about their own genealogy and place in the academy as history of religion(s) has. And this chronic condition of unease, and the multiple birthmarks that this science bears, might hold a promise that it may have something to say, something to interject and to instruct, as we aim to confront the conundrum of history's religion.

\footnotetext{
${ }^{79}$ This is evidenced by any disciplinary history of religious studies, including the title mentioned above in note 5. For a classic account, see Louis Henry Jordan, Comparative Religion: Its Genesis and Growth (Edinburgh, 1905).
}

Cite this article: Masuzawa T (2022). Theology, the Fairy Queen. Modern Intellectual History 19, 1262-1285. https://doi.org/10.1017/S1479244321000287 